\title{
The effect of dietary sucrose on blood lipids, serum insulin, platelet adhesiveness and body weight in human volunteers
}

\author{
STEPHEN Szanto \\ Ph.D., M.R.C.P.I. \\ Research Physician
}

\author{
JOHN YUDKIN \\ M.A., M.D., Ph.D. \\ Professor of Nutrition and Dietetics
}

Department of Nutrition, Queen Elizabeth College, University of London

\section{Summary}

A study was made of the effect of high or low intake of sucrose for periods of 14 days in a group of nineteen apparently healthy men.

The high sucrose diet produced no change in blood levels of cholesterol or phospholipids, or in glucose tolerance, but it produced a significant rise in triglycerides in all nineteen men. In six of them, there was in addition a rise in serum immunoreactive insulin, especially during the glucose tolerance test, and these same six subjects also showed a considerable increase in weight and a significant increase in platelet adhesiveness.

There was no difference between the six subjects and the remaining thirteen in any of the other measurements, or in the diets they consumed during the experiment. The changes produced by sucrose had disappeared, or nearly so, after 14 days of normal diet.

It is suggested that the effect of sucrose in producing hyperinsulinism may be more relevant to its possible role in the aetiology of ischaemic heart disease than its effect on blood lipids. It is further suggested that only some individuals are susceptible to the development of ischaemic heart disease by dietary sucrose, and that these may be identified as those that show 'sucrose-induced hyperinsulinism'.

\section{Introduction}

It is widely accepted that ischaemic heart disease (IHD) is a disease of affluence. Both longitudinal and cross-sectional studies have shown that the major dietary characteristic of affluence is a replacement of increasing amounts of starch by sugar (sucrose), so that in the United Kingdom during the last 200 years the proportion of sucrose has risen from less than $2 \%$ to about $35 \%$ of the total dietary carbohydrate (Yudkin, 1964). Relevant experiments, therefore, are those that study the effects of diets in which the relative proportion of these two major dietary carbohydrates is changed. We have conduc- ted such an experiment on nineteen men aged 2144 years.

\section{Subjects and methods}

The subjects were volunteers from the students and staff of two London University colleges. The purpose and design of the experiment was explained to them in detail, and they were each provided with food tables and given instruction in their use and in the recording of their food intake.

After a week's preliminary study, ten of the subjects (Group A) were asked for the next 2 weeks to take diets high in sucrose, the sucrose as far as possible substituting for starch so as not to change the caloric intake (Table 1). For the following 2 weeks-weeks 4 and 5-they reverted to their normal diets. For the next 2 weeks-weeks 6 and 7 they were asked to take diets with virtually no

TABLE 1. Experimental design

\begin{tabular}{ccll}
\hline Period & No. of days & Group A & Group B \\
\hline I & 7 & Preliminary & Preliminary \\
II & 14 & Sucrose & Starch \\
III & 14 & Rest & Rest \\
IV & 14 & Starch & Sucrose \\
V & 14 & Rest & Rest \\
\hline
\end{tabular}

sucrose, making up in calories by increasing their starch intake. Finally they were again allowed to eat their normal diet. The remaining nine subjects (Group B) followed a similar procedure, but took the low-sucrose diets in weeks 2 and 3 , and the highsucrose diets in weeks 6 and 7. At the end of the 1st week, and thereafter at intervals of 2 weeks, the subjects were weighed, their glucose tolerance determined, the insulin response to this test measured, and the plasma lipids assayed. In addition, we measured platelet adhesiveness, plasma fibrinogen and clot lysis time.

Blood was taken from a forearm vein after an overnight fast. Then $50 \mathrm{~g}$ glucose was given by mouth, 
and further blood samples taken 30 and $120 \mathrm{~min}$ later. In all three samples, blood glucose was determined by the oxidase method of Huggett \& Nixon (1957) and insulin by immunoassay (Hales \& Randle, 1963). In the sample of fasting blood, cholesterol was measured by the method of Zlatkis, Zak \& Boyle (1953) as modified by Henly (1957), triglyceride by the method of Handel \& Zilversmit (1957), phospholipid by the method of Bartlett (1959), fibrinogen by the method of Ingram (1961) and clot lysis time by the method of Fearnley, Balmforth \& Fearnley (1957).

Platelet adhesiveness was measured after 20 min rotation (Wright, 1941); no correction was made for the haematocrit values of the blood samples, since they all fell within the range $35-48 \%$.

Each subject was given a specially prepared booklet of dietary instructions and a diary in which he recorded the foods and drinks he consumed and their quantities.

\section{Results}

We have combined the results of the different dietary treatments, so that we present them as if both groups followed the same experimental design. We feel justified in doing this because the initial values for the two groups of subjects were very similar (Table 2). Moreover, as we shall see, the effects of the high-sucrose diet had disappeared at the end of the subsequent 2-week rest period, except for a very small residual effect on serum insulin levels.

Neither the increase nor the decrease in sugar intake produced a significant change in the level of
TABLE 2. Initial findings in nineteen male subjects (mean and range)

\begin{tabular}{|c|c|c|}
\hline & $\begin{array}{c}\text { Group A } \\
\text { (ten subjects) }\end{array}$ & $\underset{\text { (nine subjects) }}{\text { Group B }}$ \\
\hline Age (years) & $28(23-44)$ & $28(22-41)$ \\
\hline Height (cm) & $175(165-188)$ & $174(163-183)$ \\
\hline Weight (kg) & $73 \cdot 7(58 \cdot 3-81 \cdot 5)$ & $72 \cdot 4(61 \cdot 0-74 \cdot 9)$ \\
\hline Daily kCal & $3420(2520-4150)$ & $3370(3070-3640)$ \\
\hline $\begin{array}{l}\text { Diet (g/day) } \\
\text { Protein } \\
\text { Fat } \\
\text { Carbohydrate } \\
\text { Sucrose }\end{array}$ & $\begin{array}{l}85(72-108) \\
112(98-182) \\
509(301-599) \\
167(98-209)\end{array}$ & $\begin{array}{l}83(71-96) \\
116(100-149) \\
480(402-656) \\
163(93-248)\end{array}$ \\
\hline $\begin{array}{l}\text { Serum lipids (mg/100 n } \\
\text { Cholesterol } \\
\text { Phospholipid } \\
\text { Triglyceride }\end{array}$ & $\begin{array}{l}\text { nl) } \\
240(199-272) \\
222(187-261) \\
137(98-168)\end{array}$ & $\begin{array}{l}258(213-281) \\
238(199-274) \\
149(122-176)\end{array}$ \\
\hline $\begin{array}{c}\text { Blood glucose }(\mathrm{mg} / 100 \\
0 \mathrm{~min} \\
30 \mathrm{~min} \\
120 \mathrm{~min}\end{array}$ & $\begin{array}{l}\text { ml) } \\
\qquad 88(64-72) \\
94(91-104) \\
66(59-72)\end{array}$ & $\begin{array}{c}70(61-81) \\
104(94-108) \\
70(59-82)\end{array}$ \\
\hline $\begin{array}{l}\text { Serum insulin }(\mu \mathrm{U} / \mathrm{ml}) \\
0 \mathrm{~min} \\
30 \mathrm{~min} \\
120 \mathrm{~min}\end{array}$ & $\begin{array}{l}23(17-26) \\
64(49-86) \\
35(29-46)\end{array}$ & $\begin{array}{l}21(14-25) \\
62(53-75) \\
32(23-41)\end{array}$ \\
\hline 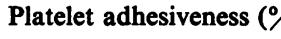 & $\% 67(59-81)$ & $68(59-82)$ \\
\hline Fibrinogen $(\mathrm{mg} / 100 \mathrm{ml})$ & $231(193-278)$ & $283(260-300)$ \\
\hline Clot lysis time (hr) & $53(3 \nmid-7 \nmid)$ & $58(31-71)$ \\
\hline
\end{tabular}

serum cholesterol or phospholipid, in glucose tolerance, in level of fibrinogen or in fibrinolytic activity (Table 3). On the other hand, the 14 days on the high-sugar diet produced a significant increase in the level of plasma triglycerides, in insulin response and in body weight, effects that were

TABLE 3. Effect of dietary sucrose in nineteen male subjects (mean)

\begin{tabular}{|c|c|c|c|c|c|}
\hline & Preliminary & Sucrose & Rest & Starch & Rest \\
\hline kCal/day & 3390 & 3350 & - & 3370 & - \\
\hline Weight (kg) & 73.0 & $74 \cdot 0^{*}$ & $73 \cdot 4$ & $73 \cdot 6$ & $73 \cdot 5$ \\
\hline Sucrose (g/day) & 164 & 438 & - & 10 & - \\
\hline $\begin{array}{l}\text { Lipids }(\mathrm{mg} / 100 \mathrm{ml}) \\
\text { Cholesterol } \\
\text { Phospholipid } \\
\text { Triglyceride }\end{array}$ & $\begin{array}{l}249 \\
230 \\
143\end{array}$ & $\begin{array}{l}248 \\
231 \\
150^{*}\end{array}$ & $\begin{array}{l}250 \\
231 \\
142\end{array}$ & $\begin{array}{l}243 \\
230 \\
140\end{array}$ & $\begin{array}{l}248 \\
230 \\
142\end{array}$ \\
\hline $\begin{array}{l}\text { Blood glucose }(\mathrm{mg} / 100 \mathrm{ml} \\
0 \mathrm{~min} \\
30 \mathrm{~min} \\
120 \mathrm{~min}\end{array}$ & $\begin{array}{l}69 \\
99 \\
68\end{array}$ & $\begin{array}{l}69 \\
99 \\
68\end{array}$ & $\begin{array}{l}68 \\
98 \\
68\end{array}$ & $\begin{array}{l}69 \\
99 \\
67\end{array}$ & $\begin{array}{r}70 \\
100 \\
68\end{array}$ \\
\hline $\begin{array}{l}\text { Serum insulin }(\mu \mathrm{U} / \mathrm{ml}) \\
0 \mathrm{~min} \\
30 \mathrm{~min} \\
120 \mathrm{~min}\end{array}$ & $\begin{array}{l}22 \\
63 \\
34\end{array}$ & $\begin{array}{l}28 \dagger \\
86 \dagger \\
49 \dagger\end{array}$ & $\begin{array}{l}23 \\
67 \\
36\end{array}$ & $\begin{array}{l}22 \\
64 \\
32\end{array}$ & $\begin{array}{l}21 \\
64 \\
32\end{array}$ \\
\hline Platelet adhesiveness $(\%)$ & 67 & 65 & 69 & 67 & 67 \\
\hline Fibrinogen $(\mathrm{mg} / 100 \mathrm{ml})$ & 255 & 256 & 259 & 257 & 255 \\
\hline Clot lysis time (hr) & 53 & 5 & 5 & 51 & $5 t$ \\
\hline
\end{tabular}

* or + Significant differences between these values and those for preceding and subsequent period. $* P<0.05 .+P<0.01$. 
completely or almost completely reversed at the end of the next 14 days of the normal diet.

A more detailed analysis of these changes shows that the effect on serum insulin levels was confined to six of the subjects (Table 4). These same six subjects also showed an increase in platelet adhesive-

TABLE 4. Effect of dietary sucrose on insulin response (mean, $\mu \mathrm{U} / \mathrm{ml}$ )

\begin{tabular}{|c|c|c|c|c|c|c|}
\hline & \multicolumn{6}{|c|}{ Period } \\
\hline & \multicolumn{3}{|c|}{ Thirteen subjects } & \multicolumn{3}{|c|}{ Six subjects } \\
\hline & $0 \mathrm{~min}$ & $30 \mathrm{~min}$ & $120 \mathrm{~min}$ & $0 \mathrm{~min}$ & $30 \mathrm{~min}$ & $120 \mathrm{~min}$ \\
\hline $\begin{array}{l}\text { Preliminary } \\
\text { Sucrose } \\
\text { Rest } \\
\text { Starch } \\
\text { Rest }\end{array}$ & $\begin{array}{l}22 \\
23 \\
22 \\
22 \\
21\end{array}$ & $\begin{array}{l}63 \\
65 \\
65 \\
64 \\
64\end{array}$ & $\begin{array}{l}33 \\
33 \\
34 \\
33 \\
31\end{array}$ & $\begin{array}{l}23 \\
39 * \\
25 \\
22 \\
23\end{array}$ & $\begin{array}{c}64 \\
131^{*} \\
72 \\
64 \\
63\end{array}$ & $\begin{array}{l}34 \\
84^{*} \\
40 \\
32 \\
34\end{array}$ \\
\hline
\end{tabular}

*Significant difference between these values and those for preceding and subsequent period $(P<0.01)$.

ness, as well as a much greater increase in body weight than did the other thirteen subjects (Tables 5 and 6, Fig. 1). The weight, platelet adhesiveness and insulin levels returned to their previous values during the next 14 days when the subjects were eating their normal diet. The changes in these three parameters were confined to six out of the nineteen subjects, whereas the change in triglyceride levels, with a rise during the high-sucrose diet and subsequent fall, were the same in the six subjects as
TABLE 6. Changes in platelet adhesiveness $(\%)$ in six subjects who developed hyperinsulinism and thirteen who did not (see Table 4)

\begin{tabular}{lccccc}
\hline & \multicolumn{5}{c}{ Period } \\
\cline { 2 - 6 } & $\begin{array}{c}\text { Prelimi- } \\
\text { nary }\end{array}$ & Sucrose & Rest & Starch & Rest \\
\hline Thirteen subjects & 67 & 67 & 68 & 69 & 66 \\
Six subjects & 68 & $60^{*}$ & 71 & 65 & 68 \\
\hline
\end{tabular}

*Significant difference between this value and those for preceding and subsequent period $(P<0.05)$.

in the remaining thirteen. Moreover, there was nothing in the experimental diets or in the original measurements - age, weight, height, blood pressure, smoking habits, blood lipids, diet, glucose tolerance or insulin response-that distinguished these six subjects from the other thirteen (Table 7).

\section{Discussion}

Our primary object in carrying out this experi- 은 ment was to discover a further link between the ingestion of sucrose and the production of ischaemic $\mathcal{D}$ heart disease. The great difficulty that has been encountered in producing in experimental animals an exact parallel to human ischaemic heart disease, and to a lesser extent its precursor atherosclerosis has directed research towards the discovery of factors that produce what are usually accepted as concomitants to the disease. This is the reason why ${ }^{+}$

TABLE 5. Weight changes in six subjects who developed hyperinsulinism and thirteen who did not (see Table 4) [mean, $\mathrm{kg}$ (and range)]

\begin{tabular}{lccc}
\hline & $\begin{array}{c}\text { Average change } \\
\text { during each week } \\
\text { of experiment }\end{array}$ & $\begin{array}{c}\text { After high- } \\
\text { sucrose diet } \\
\text { for 14 days }\end{array}$ & $\begin{array}{c}\text { After reversion } \\
\text { to normal diet } \\
\text { for 14 days }\end{array}$ \\
\hline Thirteen subjects & $(-0.5-+0.1$ & $\begin{array}{c}+0.4 \\
(0-+0.9)\end{array}$ & $\begin{array}{c}+0.05 \\
(-1.8-+2.8)\end{array}$ \\
Six subjects & $(-0.1-+0.05)$ & $(+1.4-+2.7)$ & $(-3.2--1.4)$ \\
\hline
\end{tabular}

*Significant difference between this value and those for preceding and subsequent period $(P<0.01)$.

TABLE 7. Findings in six subjects who developed hyperinsulinism and thirteen subjects who did not (see Table 4)

\begin{tabular}{|c|c|c|c|c|c|c|c|c|}
\hline & \multirow{2}{*}{$\begin{array}{c}\text { Age } \\
\text { (years) }\end{array}$} & \multirow{2}{*}{$\begin{array}{c}\text { Height } \\
\text { (cm) }\end{array}$} & \multirow{2}{*}{$\begin{array}{l}\text { Weight } \\
\text { (kg) }\end{array}$} & \multicolumn{3}{|c|}{ Daily diet } & \multicolumn{2}{|c|}{$\begin{array}{l}\text { Serum triglyceride } \\
(\mathrm{mg} / 100 \mathrm{ml})\end{array}$} \\
\hline & & & & $\mathbf{k C a l}$ & Pr.g. & Suc.g. & Mean & Range \\
\hline \multicolumn{9}{|l|}{ Initial findings } \\
\hline Thirteen subjects & $27 \cdot 5$ & 175 & $72 \cdot 5$ & 3360 & 84 & 163 & 139 & ( 98-169) \\
\hline Six subjects & $29 \cdot 5$ & 174 & $74 \cdot 5$ & 3460 & 84 & 166 & 151 & $(132-176)$ \\
\hline \multicolumn{9}{|l|}{ High-sucrose diet } \\
\hline Thirteen subjects & $27 \cdot 5$ & 175 & $72 \cdot 5$ & 3330 & 83 & 431 & 146 & $(115-159)$ \\
\hline Six subjects & $29 \cdot 5$ & 174 & $74 \cdot 5$ & 3400 & 81 & 452 & 158 & $(139-179)$ \\
\hline
\end{tabular}


such a great deal of attention has been paid to raised levels of blood lipids, and why it is now common to ascribe aetiological significance in IHD, or therapeutic effect, to agents simply on the basis that they affect blood lipids.

That dietary sucrose can cause an increase in serum triglycerides in man is now well established, though most of the experiments hitherto reported have used diets that are quite different from those normally consumed (Macdonald \& Braithwaite, 1964; Akinyanju et al., 1968). Although the amounts of sugar eaten by our subjects during the highsucrose period were three or more times as much as the average intake in this country, there are at least a few people who normally consume amounts of this order (Salter \& Yudkin, unpublished).

It has been suggested that sucrose produces an increase in level of triglyceride because it produces an increase of weight (Nutr. Rev., 1966). We have previously shown, with men consuming an 'atherogenic' diet, that the increase in the lipid can occur without weight gain (Akinyanju et al., 1968). In our present experiment, thirteen subjects showed

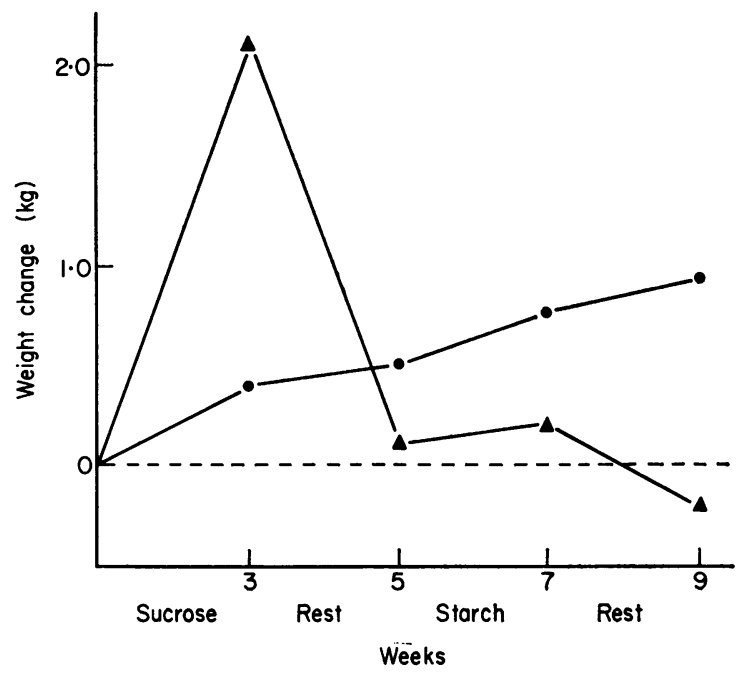

FIG. 1. Change in weight of the six subjects (A) that showed hyperinsulinism, and of the thirteen subjects (O) that did not.

variable, small and usually insignificant changes of weight during the 9 weeks, while six subjects showed a considerable increase after 2 weeks on the highsucrose diet, and a decrease to the previous value in the following 2 weeks. Nevertheless, in both sets of subjects there was a very similar rise in triglycerides induced by the high sucrose diet, and a fall to the previous level when the subjects reverted to their normal diet.

Much more striking, however, than the rise in serum lipids observed in all of our subjects was the great increase in levels of serum insulin in six of them - the same six that showed a large increase in weight and an increase in platelet adhesivenessduring the 2 weeks of high-sucrose diet. In these subjects, the level of insulin was raised both in the fasting state and after the ingestion of glucose. Since the level of insulin rose to more than $100 \mu \mathrm{U} / \mathrm{ml}$ serum, these subjects can be said to have shown hyperinsulinism according to the definition of Grodsky et al. (1965). The high levels of insulin caused by the high sucrose diet were not associated with any change in the levels of blood glucose which remained within normal limits. It is likely that a decrease in glucose tolerance would have occurred if the high-sucrose diet had been continued for a longer time, as shown in the experiments of Cohen et al. (1966).

Although we do not yet know how much of the increase in weight was due to water retention and how much to fat synthesis, the association between the two features of weight gain and hyperinsulinism recalls the association between obesity and hyperinsulinism (Rabinovitz \& Zierler, 1962; Samaan et al., 1965).

The fact that all our subjects responded to dietary sucrose by a rise in triglyceride, but only some of them responded by a rise in insulin, supports the view of Nikkilä and his colleagues (1965) that 'disordered insulin-glucose homeostasis operates through a mechanism different from that of hyperlipidaemia'. That only about one-third of our subjects showed hyperinsulinism after the highsucrose diet may be because only these were specially susceptible. This recalls the suggestion that only some people have a defect in one or other part of the insulin mechanism, which makes them susceptible to diabetes mellitus (Vallance-Owen \& Ashton, 1963) or to obesity (Butterfield, 1967). It recalls also the experiments that demonstrate that sucrose may produce its effects upon enzymes and upon blood lipids through different mechanisms (Aitken, Robinson \& Yudkin, 1967; Akinyanju \& Yudkin, 1967).

Evidence is growing that hyperinsulinism may be a more relevant factor in the production of IHD than an increase in particular blood lipids. The injection of insulin into rats increases the incorporation of labelled glucose or acetate into aortic lipid (Stout, 1968), and oral administration of carbutamide to cockerels increases the degree of spontaneous atherosclerosis (Härtel, Punsar \& Louhija, 1968). These facts support the view of Mahler (1965) that insulin may be an important factor in the development of atherosclerosis; it may indeed turn out that insulin is the beginning of the final common path to the production of IHD. If we accept the view that an increase in platelet adhesiveness is an im- 
portant factor in the production of occlusive arterial disease, it would be relevant that sucrose produced in our experiment an increase both in insulin and in platelet adhesiveness in the same susceptible subjects.

One can now begin to explain the effects of the various factors known to be associated with IHD in terms of an association with levels of circulating insulin. Peripheral vascular disease, maturity-onset diabetes, obesity, smoking and hypertension all predispose to IHD, and all are associated with hyperinsulinism (Yalow \& Berson, 1960; Rabinovitz \& Zierler, 1962; Welborn et al., 1966; Kingsbury \& Jarrett, 1967; Szanto, 1967). Conversely physical exercise and weight reduction, which reduce the risk of IHD, are associated with a reduction in circulating insulin (Devlin, 1963; Szanto, 1968). Low levels of insulin are also found in the diabetes of chronic pancreatitis, in which vascular complications are said to be relatively uncommon (Joffe et al., 1968).

We may now add sucrose to the list of agentsdiabetes, obesity, smoking and hypertensionthat produce hyperinsulinism. This is further evidence for the hypothesis that, like these other agents, sucrose increases an individual's proneness to occlusive arterial disease.

The hyperinsulinism caused by dietary sucrose may be responsible for many of the biochemical changes that this substance has increasingly been found to induce (see for example Yudkin, 1967). It will be useful we believe to bear this possibility in mind in future studies of the biochemical changes produced by sucrose. Similarly, if hyperinsulinism is a factor closely related to the underlying abnormality in IHD, we must not expect other changessecondary and more remote-to be equally uniform in subjects with the disease.

In the light of this discussion, we suggest that only a proportion of the population is susceptible to the development of occlusive atherosclerotic disease following an habitual high consumption of sucrose. We believe that the sucrose leads, after many years, to an increase in insulin levels in those people that are susceptible. If these suggestions prove correct, such individuals might be identified before they develop overt disease by determining the effect upon their insulin levels of the challenge of a high consumption of sucrose for a few days; they might show what we may call 'sucrose-induced hyperinsulinism'. We would then have a relatively simple predictive test for the identification of susceptible persons who will develop IHD if they habitually consume large amounts of sucrose. We do not yet know whether these are the same persons as are susceptible because of cigarette smoking or some other predisposing factor.
There is a further consequence that we can derive from our hypothesis. It is that men with overt occlusive arterial disease should include those whose insulin levels have been increased by a high continuing intake of sucrose. Although it will also include those whose insulin levels have been increased by cigarette smoking or hypertension, we should nevertheless expect that persons with a high sucrose intake will tend to congregate among those with high serum insulin levels; those with low sucrose intake will be more likely to congregate among those with low insulin levels. In general, that is, men with occlusive arterial disease should show a correlation between serum insulin level and sucrose intake. On the other hand, men who by middle age have developed no symptoms or signs of atherosclerosis will be composed largely of the nonsusceptible part of the population. Whatever their intake of sugar, this would not affect their serum insulin levels, so that we would expect this group to show little or no relationship between the insulin level and sucrose intake. This prediction of the presence or absence of a relationship between insulin and sucrose intake in these two groups has already been tested, and the results are reported in the following paper (Yudkin, Szanto \& Kakkar, 1969).

\section{Acknowledgments}

We are grateful to the British Heart Foundation for a grant in support of this work.

\section{References}

Aitken, J., Robinson, D. \& Yudkin, J. (1967) Effects of dietary carbohydrate on some liver enzymes. Proc. Nutr. Soc. 26, xxx.

Akinyanju, P.A., Qureshi, R.U., Salter, A.J. \& Yudkin, J. (1968) Effect of an 'Atherogenic' diet containing starch or sucrose on the blood lipids of young men. Nature (Lond.), 218, 975.

Akinyanju, P.A. \& Yudkin, J. (1967) Effects of dietary carbohydrates on the serum lipids of the rat. Proc. Nutr. Soc. 26, xxxi.

Bartlett, G.R. (1959) Phosphorus assay in column chromatography. J. biol. Chem. 234, 466.

ButTerfield, W.J.H. (1967) Third Symposium on Advanced Medicine. Proceeding of a Conference held at the Royal College of Physicians of London, 13th February to 17th February. J. roy. Coll. Physns, Lond. 1, 276.

Cohen, A.M., Teitelbaum, A., Balogh, M. \& Groen, J.J. (1966) Effect of interchanging bread and sucrose as main source of carbohydrate in a low fat diet on the glucose tolerance curve of healthy volunteer subjects. Amer. J. clin. Nutr. 19, 59.

Devin, J.G. (1963) The effect of training and acute physical exercise on plasma insulin-like activity. Ir. J. med. Sci. 6, 423.

Fearnley, G.R., Balmforth, G. \& Fearnley, E. (1957) Evidence of a diupnal fibrinolytic rhythm; with a simple method of measuring natural fibrinolysis. Clin. Sci. 16, 645. 
Grodsky, G.M., Karam, J.H., Pavlatos, F.C. \& Forsham, P.H. (1965) Serum-insulin response to glucose in prediabetic subjects. Lancet, i, 290.

Hales, C.J. \& Randle, P.J. (1963) Immunoassay of insulin with insulin-antibody precipitate. Biochem. J. 88, 137.

HANDEl, E. VAN \& Zilversmit, D.B. (1957) Micromethod for the direct determination of serum triglycerides. $J$. Lab. clin. Med. 50, 152.

Härtel, G., Punsar, S. \& Louhija, A. (1968) Insulin and atherosclerosis. Lancet, ii, 920.

Henly, A.A. (1957) The determination of serum cholesterol. Analyst, 82, 286.

Huggett, A. St G. \& Nixon, D.A. (1957) Use of glucose oxidase, peroxidase, and o-dianisidine in determination of blood and urinary glucose. Lancet, ii, 368 .

INGRAM, G.I.C. (1961) A suggested schedule for the rapid investigation of acute haemostatic failure. J. clin. Path. $14,356$.

JofFe, B.I., BANK, S., JACKSON, W.P.U., Keller, P., O'Reilly, I.G. \& VINIK, A.I. (1968) Insulin reserve in patients with chronic pancreatitis. Lancet, ii, 890.

KINGSBURY, K.J. \& JARRETT, R.J. (1967) Effects of adrenaline and of smoking in patients with peripheral atherosclerotic vascular disease. Lancet, ii, 22.

Macdonald, I. \& Braithwaite, D.M. (1964) The influence of dietary carbohydrates on the lipid pattern in serum and in adipose tissue. Clin. Sci. 27, 23.

MAHLER, R. (1965) Diabetes and arterial lipids. Quart. J. Med. 34, 484.

Nikkilä, E.A., Miettinen, T.A., Vesenne, M.R. \& Pelkonen, R. (1965) Plasma insulin in coronary heartdisease. Lancet, ii, 508.

Nutr. Rev. (1967) Dietary sucrose restriction and blood lipid levels. 25, 172.

Rabinovitz, D. \& ZierleR, K.L. (1962) Role of free fatty acids in forearm metabolism in man, quantitated by use of insulin. J. clin. Invest. 41, 2191.
SamaAn, N., Brown, J., Fraser, R. \& Trayner, I. (1965) Effect of obesity and of starvation on insulin activity. Brit. med. J. 1, 1153.

Stout, R.W. (1968) Insulin stimulated lipogenesis in arterial tissue in relation to diabetes and atheroma. Lancet, ii, 702.

Szanto, S. (1967) Smoking and atherosclerosis. Brit. med. $J$. 3, 178 .

Szanto, S. (1968) Effects of obesity and weight reduction on serum insulin levels. Pioc. Nutr. Soc. 27, 11A.

Vallance-OWen, J. \& Ashton, W.L. (1963) Cardiac infarction and insulin antagonism. Lancet, i, 1226.

Welborn, T.A., Breckenridge, A., Rubinstein, A.H., Dollery, C.T. \& Fraser, T.R. (1966) Serum-insulin in essential hypertension and in peripheral vascular disease. Lancet, i, 1336.

Wright, H.P. (1941) The adhesiveness of blood platelets in normal subjects with varying concentrations of anticoagulants. J. Path. Bact. 53, 255.

YALOW, R.S. \& Berson, S.A. (1960) Plasma insulin concentrations in non-diabetic and early diabetic subjects. Determinations by a new sensitive immuno-assay technic. Diabetes, 9, 254.

YUDKIN, J. (1964) Patterns and trends in carbohydrate consumption and their relation to disease. Proc. Nutr. Soc. 23, 149.

YudKIN, J. (1967) Why blame sugar? Chemy Ind. 1464.

Yudkin, J., Szanto, S. \& Kakkar, V.V. (1969) Sugar intake, serum insulin and platelet adhesiveness in men with and without peripheral vascular disease. Postgrad. med. J. 45, 608.

Zlatkis, A., ZAK, B. \& Boyle, A.J. (1953). A new method for the direct determination of serum cholesterol. J. Lab. clin. Med. 41, 486. 